\title{
EVALUASI KESESUAIAN LAHAN UNTUK REHABILITASI HUTAN MANGROVE KOTA LANGSA ACEH
}

\author{
Iswahyudi ${ }^{1}$, \\ Cecep Kusmana², \\ Aceng Hidayat ${ }^{3}$, \\ Bambang Pramudya Noorachmat ${ }^{4}$ \\ ${ }^{1}$ Program Studi IImu Pengelolaan Sumber Daya Alam dan Lingkungan, IPB \\ 2Fakultas Kehutanan, Institut Pertanian Bogor. \\ 3Fakultas Ekonomi Manajemen, Institut Pertanian Bogor. \\ ${ }^{4}$ Fakultas Teknologi Pertanian, Institut Pertanian Bogor. \\ e-mail: Iswahyudi@unsam.ac.id
}

\begin{abstract}
Mangrove ecosystem has the role of interface ecosystem between land and sea. It has social, economic and ecological functions. The decreasing quality and quantity of mangrove mangrove forest has resulted in environmental damage. Langsa City has mangrove forest in damaged condition because of conversion into fish ponds, illegal logging, pollution and settlements. The purpose of this research was to determine the level of land suitability of rehabilitated mangrove areas. The research was conducted in Langsa City, Aceh. Location and method of this research determined by purposive and descriptive with survey techniques. The Analytical method used is a suitability analysis. According to land suitability matrix and spatial analysis, there were three types of mangroves that can be used for rehabilitation programs in the study area like Rhizophora spp., Avicennia spp., and Sonneratia spp. In land suitability level, Rhizophora spp. had the highest of land suitability around 1.263,92 ha (66,88\%).
\end{abstract}

Keywords: land suitability, mangrove ecosystem, rehabilitation

\begin{abstract}
ABSTRAK
Ekosistem mangrove merupakan wilayah yang berperan sebagai peralihan antara daratan dan lautan yang mempunyai fungsi ekologi, sosial ekonomi, dan fisik. Menurunnya kualitas dan kuantitas hutan mangrove telah mengakibatkan kerusakan lingkungan. Kondisi hutan mangrove Kota Langsa pada saat ini mengalami kerusakan. Faktor utama penyebab kerusakan, antara lain konversi hutan mangrove menjadi tambak, pembalakan liar, pencemaran, dan permukiman baru. Tujuan penelitian untuk menentukan tingkat kesesuaian lahan pada areal rehabilitasi mangrove. Penelitian ini dilakukan di Kota Langsa, Aceh. Penentuan lokasi penelitian dilakukan secara purposive dan menggunakan metode deskriptif dengan teknik survei. Analisis kesesuaian lahan dan analisis spasial untuk mengetahui tingkat kesesuaian lahan mangrove digunakan dalam penelitian ini. Hasil penelitian menunjukkan, ada tiga jenis mangrove yang dapat digunakan untuk program rehabilitasi, yaitu: Rhizophora spp., Avicennia spp., dan Sonneratia spp. Berdasarkan tingkat kesesuaian lahan, jenis Rhizophora spp. mempunyai tingkat kesesuaian lahan tertinggi. Luasan lahan yang dapat ditanami jenis Rhizophora spp. seluas $1.263,92$ ha $(66,88 \%)$.
\end{abstract}

Kata kunci: ekosistem mangrove, kesesuaian lahan, rehabilitasi 
Hutan mangrove merupakan salah satu ekosistem pesisir yang paling penting dan bernilai (Aksornkoae \& Kato, 2011). Secara ekonomi hutan mangrove menghasilkan berbagai macam hasil hutan kayu dan non kayu, hasil perikanan pesisir, obat-obatan, dan jasa lingkungan (Spalding, Kainuma, \& Collins, 2010; Kathiresan, 2012). Secara ekologi, hutan mangrove adalah habitat bagi berbagai jenis fauna dan mempunyai manfaat fisik melindungi garis pantai dari bencana alam di wilayah pesisir (Kusmana, 2014).

Luas mangrove di dunia sekitar 15,2 juta ha yang menyebar di 124 negara tropik dan subtropik. Indonesia merupakan negara yang mempunyai luasan hutan mangrove terluas di dunia diikuti oleh Australia, Brazil, Nigeria dan Mexico yang mewakili 48\% dari luas hutan mangrove dunia (Lavieren, Spalding, Alongi, Kainuma, Godt, \& Adeel, 2015). Permasalahan yang dihadapi oleh ekosistem mangrove pada saat ini di seluruh dunia adalah tingginya laju kerusakan. Secara global, penurunan luasan hutan mangrove sudah mencapai $1-2 \%$ pertahun. Penurunan luasan hutan mangrove terjadi di hampir setiap negara yang memiliki hutan mangrove, dan penurunannya meningkat lebih cepat di negara-negara berkembang, di mana lebih dari $90 \%$ hutan mangrove dunia berada (Alongi, 2008; Carter, Schmidt, \& Hirons, 2015).

Penyebab utama kerusakan hutan mangrove di Asia Selatan adalah konversi untuk pertanian, tambak udang dan pengembangan pemukiman (Giri et al., 2015). Pendorong utama hilangnya mangrove di Asia Tenggara adalah konversi mangrove menjadi akuakultur, pertanian dan perkebunan kelapa sawit (Thomas, Lucas, Bunting, Hardy, Rosenquist, \& Simard, 2017). Untuk mengatasi hal tersebut, banyak kegiatan konservasi mangrove yang dilakukan. Terlepas dari kepentingan ekologi dan sosial ekonomi, konservasi mangrove yang dilakukan belum mampu menyamai laju kerusakan hutan mangrove (Richards \& Friess, 2016).

Kota Langsa Provinsi Aceh mempunyai luas hutan mangrove 6.172,42 ha. Berdasarkan Kepmenhut No. 941/Menhut-II/2013 tentang perubahan peruntukan kawasan hutan menjadi bukan hutan seluas 42.616 ha, perubahan fungsi kawasan hutan seluas 130.542 ha dan perubahan bukan kawasan hutan menjadi kawasan hutan seluas 26.461 ha di Propinsi Aceh, maka peruntukan kawasan hutan mangrove di Kota Langsa seluas 1.687,76 ha sebagai hutan lindung mangrove, seluas $3.657,12$ ha sebagai hutan produksi, seluas 676,44 sebagai hutan produksi konversi dan seluas 151,1 ha sebagai area penggunaan lain (Bapedda Kota Langsa, 2014).

Dari $6.172,42$ ha luas hutan mangrove di Kota Langsa, seluas $14,96 \%$ dalam kondisi rusak berat, seluas $22,80 \%$ dalam kondisi rusak dan seluas $62,24 \%$ dalam kondisi tidak rusak (DKPP Kota Langsa, 2014). Faktor utama yang menyebabkan kerusakan hutan mangrove di Kota Langsa antara lain adanya konversi lahan mangrove menjadi penggunaan lain, pembukaan permukiman baru, illegal logging, pencemaran, perluasan tambak dan praktik budidaya yang tidak berkelanjutan. Hal ini telah menyebabkan deforestasi ekosistem pesisir dan penurunan kualitas air di Kota Langsa.

Pemerintah Kota Langsa dalam mewujudkan keberlanjutan ekosistem mangrove telah melakukan program rehabilitasi dengan cara penanaman kembali mangrove pada beberapa lokasi seperti di Gampong Pusong Telaga Tujuh, Pelabuhan Kuala Langsa, Hutan Wisata Mangrove Kuala Langsa, dan beberapa titik yang menyebar di Kecamatan Langsa Timur, Langsa Barat, dan Langsa Baro (DKPP Kota Langsa, 2014). Menurut Schmitt \& Duke (2016), fokus perhatian utama untuk keberhasilan rehabilitasi mangrove sangat ditentukan oleh pemilihan lokasi dan jenis mangrove yang tepat, sehingga dapat meningkatkan perlindungan terhadap bibit dan hutan mangrove dari kerusakan. Pemilihan jenis mangrove yang tidak sesuai (Kodikara, Mukherjee, Jayatissa, DahdouhGuebas, \& Koedam, 2017) dan substrat yang salah akibat penanaman pada topografi yang tidak sesuai (Brown \& Lewis, 2006) adalah penyebab lain kegagalan rehabilitasi mangrove. 
Berbagai upaya perbaikan kondisi ekosistem hutan mangrove akan dapat terlaksana dengan baik apabila tersedia informasi obyektif terkait kondisi hutan dan lahan secara menyeluruh.

Penyediaan data dan informasi tersebut sangat diperlukan terutama dalam menunjang kegiatan rehabilitasi mangrove yang dilakukan, sehingga dapat menjadi acuan dalam pengalokasian sumber daya secara proporsional. Dengan demikian diharapkan tercipta daya dukung sumber daya hutan dan lahan yang optimal dan lestari, serta program rehabilitasi yang dilakukan dapat berhasil. Penelitian ini bertujuan untuk menentukan tingkat kesesuaian lahan pada areal rehabilitasi mangrove di Kota Langsa.

\section{METODE}

Penelitian ini dilakukan di Kota Langsa Propinsi Aceh. Waktu pelaksanaan penelitian mulai bulan September sampai dengan Desember 2015.

Bahan yang digunakan adalah citra satelit Landsat 7 ETM+ (tahun peliputan 2013), Peta Sistem Lahan dari RePPProT skala 1:250.000, Peta Dasar (Peta Rupa Bumi Indonesia atau tematik Kota Langsa Skala 1:50.000; Peta Jenis Tanah, Peta Penggunaan Lahan dan Peta Kelas Lereng Kota Langsa).

Peralatan yang digunakan adalah seperangkat komputer yang dilengkapi software ERDAS Imagine 9.1, ArcGIS ver 10.3, buku panduan pengenalan mangrove, refraktometer, Global Positioning System (GPS) dan kamera.

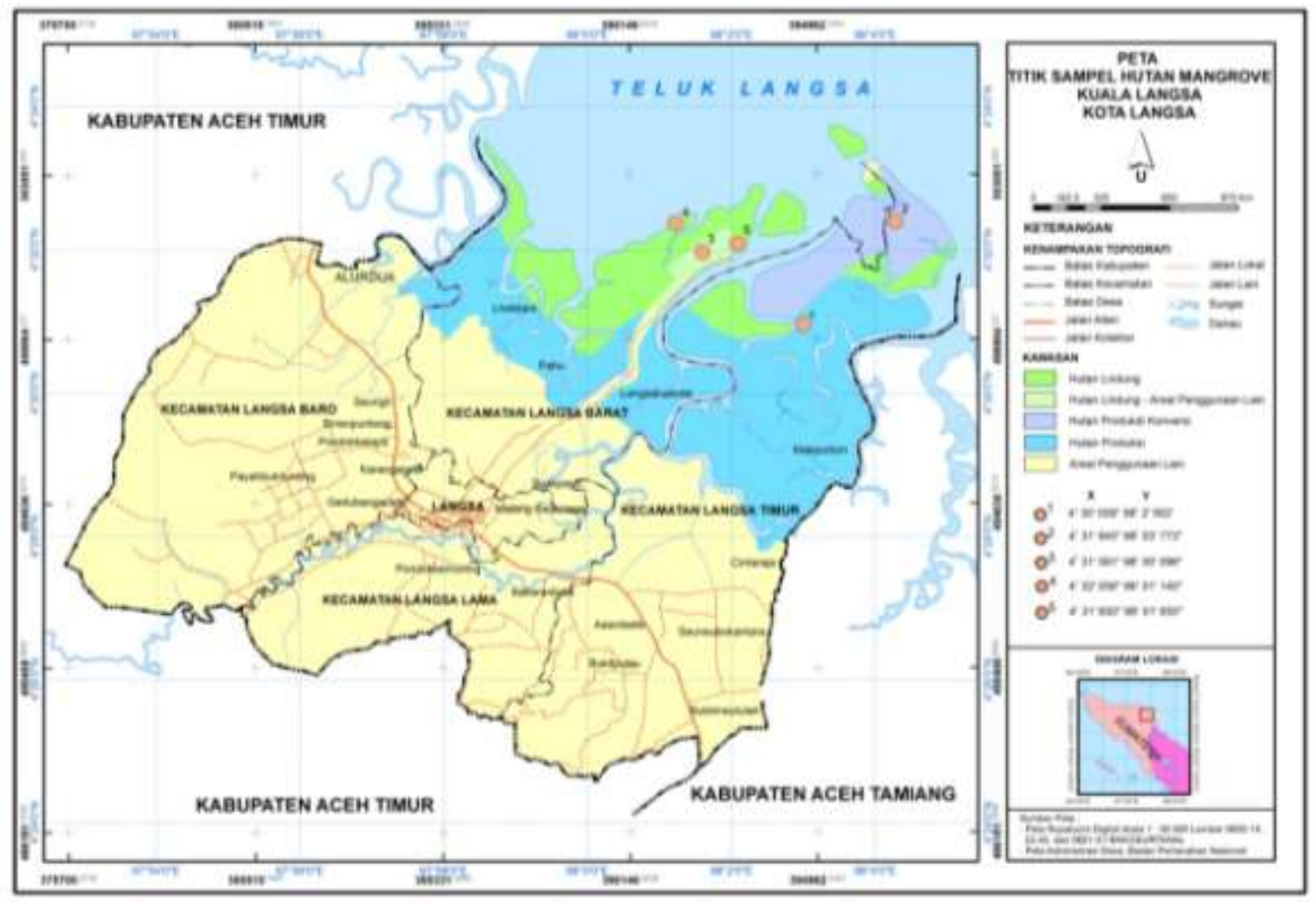

Gambar 1. Peta lokasi titik sampel 
Penelitian dilakukan menggunakan metode deskriptif dengan teknik survei. Data yang dikumpulkan berupa data primer dan data sekunder. Data primer diperoleh dari survei lapangan (data pasang surut, tekstur tanah, dan salinitas air laut) yang dilakukan pada 5 titik (Alue Tirom, Pulau Pusong, Pulau Tikus, Muara Pulau Tikus, dan Pelabuhan Kuala Langsa) (Gambar 1). Data sekunder diperoleh dari studi literatur dan instansi pemerintah.

Analisis kesesuaian lahan untuk rehabilitasi mangrove mencakup dua tahapan analisis, yaitu: penyusunan matriks kesesuaian lahan mangrove dan analisis spasial untuk mengetahui tingkat kesesuaian lahan untuk mangrove.

1. Penyusunan matriks kesesuaian lahan mangrove (Tabel 1), didasarkan pada tipe pasang, kelas penggenangan (salinitas dan frekuensi pasang), dan tipe tekstur tanah berdasarkan kriteria Watson dan de Haan dalam Kusmana et al., (2005). Watson dan de Haan membuat korelasi antara salinitas, frekuensi genangan pasang (kelas penggenangan), tipe tekstur tanah, dan jenis pohon mangrove yang dapat tumbuh pada daerah yang bersangkutan.

2. Analisis spasial untuk mengetahui tingkat kesesuaian lahan untuk mangrove, berdasarkan hasil overlay (tumpang susun) beberapa jenis peta (administrasi, jenis tanah, sistem lahan, kelas lereng, dan tutupan lahan) dan parameter-parameter kesesuaian lahan untuk mangrove (tipe pasang atau kelas penggenangan, salinitas serta frekuensi pasang dan tipe tekstur tanah).

Tabel 1. Matriks Kesesuaian Lahan Mangrove

\begin{tabular}{|c|c|c|c|}
\hline $\begin{array}{l}\text { Tipe Pasang /Kelas } \\
\text { Penggenangan } \\
\text { Watson (1928) }\end{array}$ & $\begin{array}{l}\text { Kelas Penggenangan } \\
\text { (Salinitas dan Frekuensi } \\
\text { Pasang) de Haan (1931) }\end{array}$ & Tipe Tekstur Tanah & Jenis Mangrove Dominan \\
\hline 1. All high tides & $\begin{array}{l}\text { Payau sampai masin, } \\
\text { salinitas } 10-30 \mathrm{ppt} \text {, selalu } \\
\text { tergenang ( } 1-2 \mathrm{kali} / \mathrm{hari}, \\
\text { minimal } 20 \text { hari/bulan). }\end{array}$ & $\begin{array}{l}\text { Koral, berpasir, lempung } \\
\text { berpasir }\end{array}$ & $\begin{array}{l}\text { Avicennia spp., } \\
\text { Sonneratia spp., } \\
\text { Rhizophora spp. }\end{array}$ \\
\hline 2. Medium high tides & $\begin{array}{l}10-19 \text { hari/bulan, salinitas } \\
10-30 \text { pt }\end{array}$ & Berdebu sampai liat berdebu & Bruguiera gymnorrhiza \\
\hline 3. Normal high tides & $\begin{array}{l}9 \text { hari/bulan, salinitas } 10-30 \\
\text { ppt }\end{array}$ & $\begin{array}{l}\text { Berdebu, liat berdebu } \\
\text { sampai liat }\end{array}$ & $\begin{array}{l}\text { Xylocarpus spp., } \\
\text { Scyphiphora spp., } \\
\text { Lumnitzera spp. }\end{array}$ \\
\hline 4. Spring tides only & $\begin{array}{l}\text { Beberapa hari/bulan, } \\
\text { salinitas } 0 \mathrm{ppt}\end{array}$ & Berpasir sampai liat berdebu & $\begin{array}{l}\text { Jenis-jenis marginal pada } \\
\text { lingkungan mangrove } \\
\text { seperti : Xylocarpus } \\
\text { moluccensis, Intsia bijuga, } \\
\text { Nypa fruticans, Ficus } \\
\text { retusa, Glochidion littorale. }\end{array}$ \\
\hline $\begin{array}{l}\text { 5. Storm highes tides } \\
\text { only }\end{array}$ & $\begin{array}{l}\text { Air tawar sampai payau, } \\
\text { salinitas } 0 \text { ppt (Jarang } \\
\text { tergenang pasang) }\end{array}$ & Berpasir sampai liat berdebu & $\begin{array}{l}\text { Oncosperma spp., Cerbera } \\
\text { spp. }\end{array}$ \\
\hline
\end{tabular}

Sumber: Kusmana et al., (2005)

\section{HASIL DAN PEMBAHASAN}

Hasil pengukuran didapatkan bahwa tipe pasang atau kelas penggenangan di lokasi penelitian pada seluruh lokasi pengambilan sampel all high tides. Secara umum, keseluruhan titik pengambilan sampel selalu tergenang 2 kali/hari. Tipe pasang surut di lokasi penelitian semidiurnal (pasang surut tengah harian atau harian ganda) yakni dalam waktu 24 jam terdapat 2 kali pasang 
dan 2 kali surut dengan periode pasang surut 6 jam sekali. Pasang pertama terjadi pada pukul 06.39 Waktu Indonesia Barat (WIB) dan pasang kedua terjadi pada pukul 18.41 WIB. Pasang surut ini sangat menentukan terhadap pembentukan zonasi mangrove di lokasi penelitian. Matrik penilaian kesesuian lahan mangrove disajikan pada Tabel 2.

Tabel 2. Matrik Penilaian Kesesuian Lahan Mangrove

\begin{tabular}{|c|c|c|c|c|c|}
\hline $\begin{array}{l}\text { Titik } \\
\text { Sampel }\end{array}$ & $\begin{array}{l}\text { Tipe Pasang } \\
\text { /Kelas } \\
\text { Penggenangan }\end{array}$ & $\begin{array}{c}\text { Kelas Penggenangan } \\
\text { (Salinitas dan Frekuensi Pasang) }\end{array}$ & Tekstur Tanah & $\begin{array}{l}\text { Jenis Mangrove } \\
\text { yang ditanam }\end{array}$ & $\begin{array}{l}\text { Kesesuaian } \\
\text { Lahan }\end{array}$ \\
\hline 1 & All high tides & $\begin{array}{l}\text { Payau-masin, salinitas } 20 \mathrm{ppt} \\
\text { selalu tergenang ( } 2 \text { kali/hari, } \\
\text { selama satu bulan) }\end{array}$ & Lempung Berliat & Rhizophora spp. & Sesuai \\
\hline 2 & All high tides & $\begin{array}{l}\text { Payau-masin, salinitas } 28 \mathrm{ppt} \text {, } \\
\text { selalu tergenang ( } 2 \text { kali/hari, } \\
\text { selama satu bulan) }\end{array}$ & $\begin{array}{l}\text { Lempung } \\
\text { Berpasir }\end{array}$ & Rhizophora spp. & Sesuai \\
\hline 3 & All high tides & $\begin{array}{l}\text { Payau-masin, salinitas } 27 \mathrm{ppt} \\
\text { selalu tergenang ( } 2 \text { kali/hari, } \\
\text { selama satu bulan) }\end{array}$ & Lempung & Rhizophora spp. & Sesuai \\
\hline 4 & All high tides & $\begin{array}{l}\text { Payau-masin, salinitas } 32 \mathrm{ppt} \text {, } \\
\text { selalu tergenang ( } 2 \text { kali/hari, } \\
\text { minimal } 20 \text { hari/bulan) }\end{array}$ & $\begin{array}{l}\text { Lempung Liat } \\
\text { Berpasir }\end{array}$ & $\begin{array}{l}\text { Avicennia spp.; } \\
\text { Rhizophora spp. }\end{array}$ & Sesuai \\
\hline 5 & All high tides & $\begin{array}{l}\text { Payau-masin, salinitas } 26 \mathrm{ppt} \\
\text { selalu tergenang ( } 2 \text { kali/hari, } \\
\text { selama satu bulan) }\end{array}$ & Lempung & $\begin{array}{l}\text { Avicennia spp.; } \\
\text { Sonneratia spp.; } \\
\text { Rhizophora spp. }\end{array}$ & Sesuai \\
\hline
\end{tabular}

Salinitas di lokasi penelitian berkisar antara 20-32 ppt. Nilai salinitas tertinggi didapatkan pada titik sampel 4 (Muara Pulau Tikus) dengan nilai salinitas 32 ppt. Lokasi ini berhadapan langsung dengan pantai. Nilai salinitas terendah diperoleh pada titik sampel 1 (Alue Tirom), lokasi ini merupakan wilayah yang paling dekat dengan permukiman dan banyak terdapat lokasi tambak yang dimanfaatkan oleh masyarakat untuk budidaya ikan dan udang.

Tekstur tanah pada ekosistem hutan mangrove merupakan salah satu faktor yang menentukan jenis mangrove yang dapat berkembang pada daerah tersebut. Hasil analisis menunjukkan bahwa tesktur tanah di lokasi penelitian terdiri atas empat jenis, yaitu lempung, lempung berliat, lempung liat berpasir, dan lempung berpasir. Selanjutnya untuk menilai kelas kesesuaian lahan untuk areal rehabilitasi di lokasi penelitian menggunakan data analisis tiga parameter (tipe pasang/kelas penggenangan, salinitas/frekuensi pasang, dan kelas tekstur tanah).

Jenis mangrove yang ditanam pada lokasi rehabilitasi ada 3 famili dan 8 jenis yaitu famili Avicenniaceae (Avicennia officinalis dan Avicennia marina), Rhizophoraceae (Bruguiera cylindrica, $B$. gymnorrhiza, B. parviflora, Rhizophora apiculata dan R. mucronata) dan Sonneratiaceae (Sonneratia caseolaris). Tepatnya pemilihan jenis mangrove yang ditanam pada areal dengan kondisi rehabilitasi membuat program rehabilitasi mangrove di Kota Langsa telah berhasil. Pada beberapa tempat dengan kondisi mangrove yang rusak, setelah dilakukan rehabilitasi, mangrove dapat tumbuh kembali dengan baik. Setelah diketahui kelas kesesuaian lahan untuk rehabiltasi mangrove, langkah selanjutnya dilakukan analisis spasial kesesuaian lahan areal rehabilitasi mangrove. Secara rinci, kesesuaian lahan rehabilitasi mangrove disajikan pada Tabel 3 dan peta kelas kesesuaian lahan disajikan pada Gambar 2. 
Tabel 3. Kesesuaian Lahan Rehabilitasi Mangrove

\begin{tabular}{lrc}
\hline \multirow{2}{*}{ Jenis Mangrove } & \multicolumn{2}{c}{ Luas } \\
\cline { 2 - 3 } & \multicolumn{1}{c}{ Ha } & $(\%)$ \\
\hline Rhizophora spp. & 1263,92 & 66,88 \\
Avicennia spp. & 508,96 & 26,93 \\
Sonneratia spp. & 117,01 & 6,19 \\
\hline \multicolumn{1}{c}{ Jumlah } & $\mathbf{1 8 8 9 , 8 9}$ & $\mathbf{1 0 0}$ \\
\hline
\end{tabular}

Sebanyak tiga jenis mangrove yang dapat digunakan untuk program rehabilitasi di lokasi penelitian (Tabel 3). Berdasarkan tingkat kesesuaian lahan, jenis Rhizophora spp. mempunyai tingkat kesesuaian lahan paling tinggi dibandingkan dengan kedua jenis lainnya. Luasan lahan yang dapat ditanami jenis Rhizophora spp. adalah seluas $1.263,92$ ha $(66,88 \%)$. Kekuatan dan kecocokan dari karakteristik tempat hidup sangat mempengaruhi pertumbuhan mangrove. Secara umum faktor kondisi biofisik di lokasi rehabilitasi sangat sesuai untuk pertumbuhan jenis-jenis mangrove yang ditanam. Tipe pasang surut all high tides pada seluruh titik sampel pengamatan sangat sesuai untuk pertumbuhan mangrove di lokasi penelitian. Karena perubahan tingkat salinitas pada saat pasang merupakan salah satu faktor yang membatasi distribusi jenis mangrove.

Faktor fluktuasi pasang surut dan salinitas juga menciptakan suatu ekosistem yang hanya sesuai untuk mangrove. Pasang surut juga membawa air laut ke muara melawan arah ke luar aliran air tawar yang memungkinkan mangrove tumbuh di sepanjang aliran sungai dan membawa nutrisi ke ekosistem mangrove. Fluktuasi pasang surut juga sangat penting di daerah dengan tingkat penguapan yang tinggi karena membantu mencegah kondisi hipersalinitas dalam tanah yang merugikan mangrove. Penyebaran bibit mangrove dan propagul (buah mangrove yang telah mengalami perkecambahan) dipengaruhi oleh pasang surut air laut (Odum, Mclvor, \& Smith,1982).

Dominansi jenis Rhizophora spp. diduga dipengaruhi oleh letak Kota Langsa yang berada di daerah teluk dan adanya Pulau Telaga Tujuh yang melindungi hutan mangrove di wilayah pesisir Kota Langsa dari kombinasi hempasan gelombang, angin, dan arus laut sehingga tidak menyebabkan abrasi yang dapat mengganggu pertumbuhan mangrove. Mangrove dapat tumbuh dengan baik pada daerah pengendapan dengan gelombang laut yang rendah.

Gelombang laut yang tinggi dapat mencabut mangrove karena mangrove memiliki sistem perakaran yang dangkal, selain itu gelombang laut tinggi juga akan mengurangi terjadinya pengendapan sedimentasi yang terdiri dari lumpur dan tanah liat. Sedimen tersebut mengandung banyak bahan organik yang berfungsi sebagai nutrisi bagi pertumbuhan mangrove.

Nilai salinitas di lokasi penelitian berkisar antara 20-32 ppt, berada sedikit di bawah nilai salinitas laut yang normal. Pada umumnya salinitas laut memiliki kadar garam 33-37 ppt. Untuk laut dalam salinitas bisa mencapai 34-35 ppt dan salinitas air laut di dunia rata-rata 35\% (Wenqing, Zhongzheng, Siyang, Yihui, Luzhen, \& Guanghui, 2011). Variasi nilai salinitas di lokasi penelitian dipengaruhi oleh curah hujan yang tinggi di Kota Langsa dan posisi lokasi penelitian yang merupakan muara dari empat Daerah Aliran Sungai (Krueng Bayeun, Krueng Bireum Puntong, Krueng Langsa, dan Krueng Manyak Payed) yang membawa air tawar ke laut. Banyaknya aliran air tawar yang dibawa dari hilir dan bermuara di wilayah pesisir tempat penelitian dilaksanakan, menyebabkan salinitas menjadi rendah. 


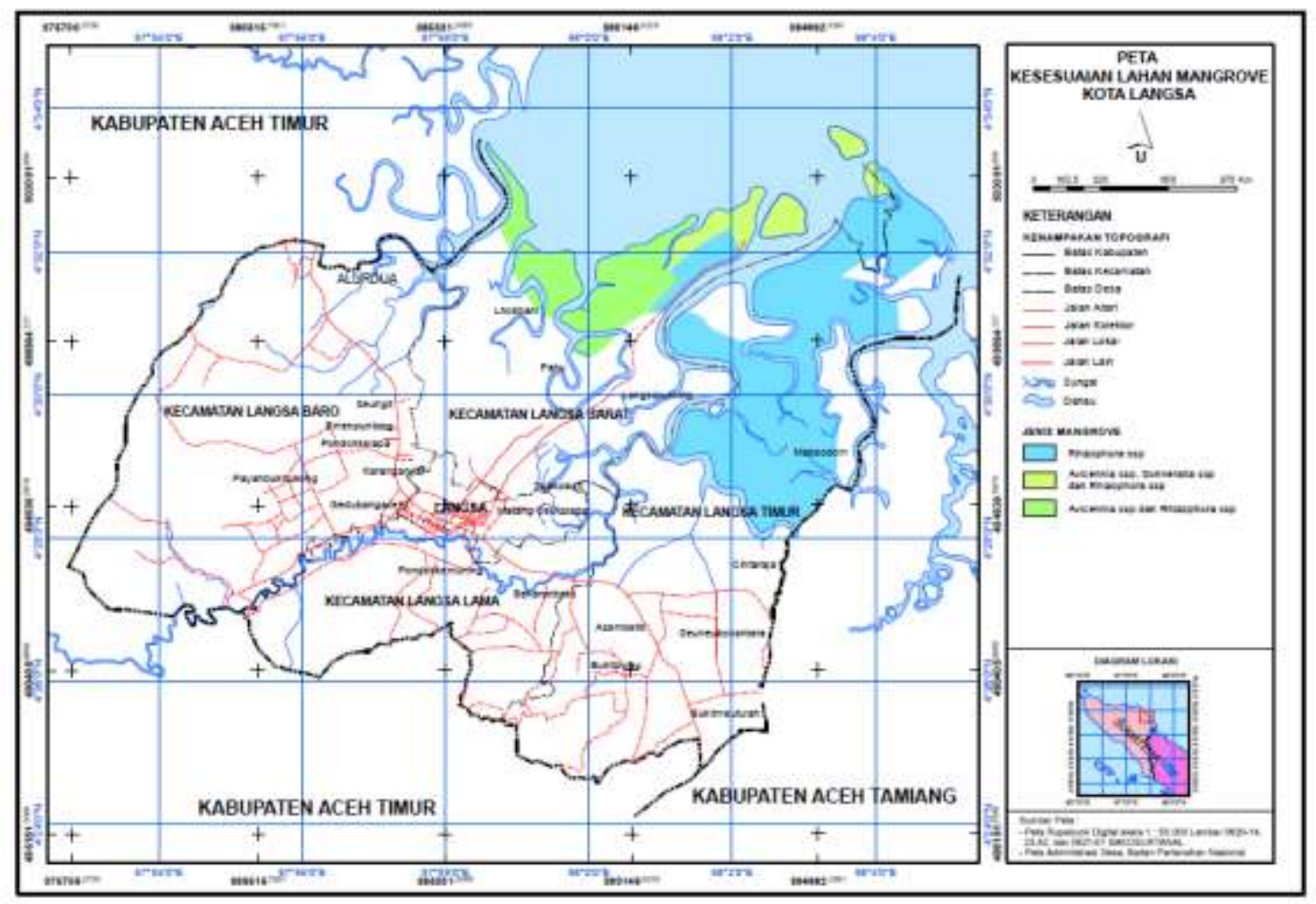

Gambar 2. Peta kesesuaian lahan mangrove

Menurut Melana, Atchue, Yao, Edwards, E.E. Melana, \& Gonzales (2000), jenis R. mucronata sesuai tumbuh pada lahan berlumpur dan dipengaruhi oleh keberadaan sungai. Noor, Khazali, \& Suryadiputra, (2006) menyatakan jenis A. marina paling sesuai tumbuh di daerah yang jauh dari sungai, karena pasokan air tawarnya sedikit, sehingga salinitasnya tinggi, $R$. mucronata sesuai tumbuh pada lokasi yang rendah di mana air laut hampir selalu hadir secara teratur, dan $B$. gymnorrhiza sesuai tumbuh pada lokasi dekat sungai di mana selalu ada aliran air tawar.

Jenis Avicennia spp. sangat sesuai tumbuh di sepanjang garis pantai dan di lokasi pantai yang terlindung. Dari hasil pengamatan lapangan, jenis $A$. alba banyak dijumpai pada titik sampel 4 yang berada di sepanjang garis pantai dan muara sungai. Sedangkan pada titik sampel 5 yang berada di Pelabuhan Kuala Langsa, jenis $A$. marina mendominasi pada zona paling depan. Menurut Kathiresan (2003), untuk daerah dengan kandungan salinitas tinggi lebih baik memilih jenis $A$. Marina, sementara daerah dengan kandungan salinitas rendah lebih baik memilih jenis $B$. gymnorrhiza. Selain itu, jenis Avicennia spp. mampu memerangkap 30\% sedimen lebih efektif dari Rhizophora spp. yang disebabkan oleh struktur perakaran yang kuat dan mampu bertahan pada salinitas tinggi di mana pertumbuhan maksimal terjadi.

Tekstur tanah di lokasi penelitian yang substratnya mengandung lumpur lunak sangat sesuai untuk pertumbuhan jenis Rhizophora spp. Menurut Field (1998), mangrove tumbuh pada substrat yang mempunyai kombinasi pasir, lumpur, dan liat yang kaya bahan organik. Substrat tanah dapat mempengaruhi distribusi jenis mangrove. Mangrove tumbuh sangat sesuai pada garis pantai berlumpur dengan gelombang yang rendah di mana ada zona intertidal yang sesuai dan luas dengan pasokan sedimen organik yang berlimpah. Melana et al., (2000), menambahkan bahwa substrat yang 
sesuai untuk jenis Brugueira spp. adalah substrat lempung berpasir atau lempung berdebu. Jenis Rhizophora spp. dan Avicennia spp. bisa tumbuh baik pada tanah lunak (belum begitu matang) dan berlumpur. Sedangkan jenis Sonneratia spp. dapat ditanam di tanah yang lebih keras atau lebih matang, biasanya lebih dekat ke arah darat.

Substrat lempung berpasir merupakan substrat yang sangat cocok untuk pertumbuhan jenis Rhizophora spp. Bentuk perakaran Rhizophora spp. yang menjangkar dan rapat menyebabkan terbentuknya substrat. Perakaran inilah yang menjadikan proses penangkapan partikel debu di tegakan Rhizophora spp. berjalan sempurna. Ketika terjadi arus balik, partikel-partikel debu terhambat oleh perakaran-perakaran tersebut. Oleh karena itu jenis Rhizophora spp. sangat menyukai substrat lempung berpasir (Kusmana et al., 2005). Substrat berlumpur atau lempung berpasir merupakan substrat yang sesuai untuk pertumbuhan $R$. mucronata dan S. alba (Mirerra, Ochiewo, Munyi, \& Muriuki, 2013).

Evaluasi kesesuaian lahan pada areal rehabilitasi mangrove penting dilakukan, hal ini berdasarkan dari pengalaman rehabilitasi yang pernah dilakukan di Kota Langsa yang mengalami banyak kegagalan. Pasca dilanda bencana gempa dan tsunami pada tahun 2004 di Propinsi Aceh yang mengakibatkan ratusan ribu orang meninggal dunia dan kerusakan yang sangat parah di daratan, maka mulai dilakukan berbagai macam program rehabilitasi dan rekonstruksi. Salah satu program yang dilakukan khususnya di wilayah pesisir dan bantaran sungai adalah rehabilitasi hutan mangrove. Sejak tahun 2006, di Kota Langsa banyak dilakukan rehabilitasi mangrove. Rehabilitasi ini antara lain dilakukan oleh Satuan Kerja Badan Rehabilitasi dan Rekonstruksi Nanggroe Aceh Darussalam-Nias (Satker BRR NAD-Nias), Balai Pengelolaan Daerah Aliran Sungai (BPDAS) Krueng Aceh dan Dinas Kelautan, Perikanan dan Pertaniani (DKPP) Kota Langsa (Tabel 4).

Tabel 4. Rincian Program Rehabilitasi Mangrove di Kota Langsa

\begin{tabular}{|c|c|c|c|c|}
\hline Kecamatan & $\begin{array}{l}\text { Luas Tanam } \\
\text { (ha) }\end{array}$ & Jenis & $\begin{array}{l}\text { Tahun } \\
\text { Tanam }\end{array}$ & Pelaksana \\
\hline Langsa Barat & 200 & $\begin{array}{l}\text { R. mucronata, } \\
\text { R. apiculata }\end{array}$ & 2006 & Satker BRR Pesisir \\
\hline Langsa Kota & 150 & $\begin{array}{l}\text { R. mucronata, } \\
\text { R. apiculata }\end{array}$ & 2006 & Satker BRR Pesisir \\
\hline Langsa Timur & 100 & $\begin{array}{l}\text { R. mucronata, } \\
\text { R. apiculata }\end{array}$ & 2006 & BP DAS Krueng Acer \\
\hline Langsa Barat & 60 & $\begin{array}{l}\text { B. gymnorrhiza, } \\
\text { R. apiculata, }\end{array}$ & 2012 & DKPP Kota Langsa \\
\hline Langsa Kota & 20 & $\begin{array}{l}\text { R. mucronata, } \\
\text { S. caseolaris }\end{array}$ & 2012 & DKPP Kota Langsa \\
\hline Langsa Barat & 50 & $\begin{array}{l}\text { B. gymnorrhiza, } \\
\text { R. apiculata, }\end{array}$ & 2013 & DKPP Kota Langsa \\
\hline
\end{tabular}

Sumber : DKPP Kota Langsa (2014)

Luas tanam mangrove yang telah dilakukan selama program rehabilitasi adalah seluas 580 ha (Tabel 4). Umumnya jenis mangrove yang ditanam dari famili Rhizophoraceae. Lokasi penanaman mangrove banyak dilakukan pada areal tambak yang tidak produktif, Pulau Pusong Telaga Tujuh, 
bantaran sungai, dan pada areal hutan lindung mangrove yang terdapat di Kuala Langsa.

Berdasarkan hasil kegiatan evaluasi terhadap program penanaman mangrove yang dilakukan oleh Satker BRR-NAD Nias pada tahun 2006 di areal seluas 350 ha, tingkat keberhasilan tumbuhnya mangrove hanya sekitar 47\%. (Satker BRR-NAD Nias, 2008).

Rendahnya keberhasilan rehabilitasi mangrove yang dilakukan oleh Satker BRR-NAD Nias pada awal program ini dijalankan karena tidak adanya bibit mangrove yang tersedia di Kota Langsa dan kesalahan pemilihan lokasi penanaman. Karena tidak tersedianya bibit mangrove pada waktu itu, maka pihak Satker BRR-NAD Nias terpaksa mendatangkan bibit mangrove dari Kota Banda Aceh yang kondisi biofisik tempat tumbuhnya berbeda dengan di Kota Langsa, sehingga banyak mangrove yang ditanam mati. Menurut Primavera \& Esteban (2008), rendahnya keberhasilan rehabilitasi mangrove di Filipina dalam dua dekade terakhir disebabkan oleh kesalahan pemilihan jenis dan lokasi penanaman yang tidak sesuai. Banyak kasus kegagalan rehabilitasi mangrove di Malaysia disebabkan oleh kesalahan dalam pemilihan lokasi penanaman dan jenis mangrove yang ditanam tidak sesuai (Jusoff, 2013).

Menurut DKPP Kota Langsa (2014), di Kota Langsa dijumpai 9 famili dan 19 jenis mangrove sejati. Di seluruh dunia dijumpai 60 jenis tumbuhan mangrove sejati (Saenger, Heger, \& Davies, 1983). Dengan demikian terlihat bahwa hutan mangrove di Kota Langsa merupakan salah satu wilayah yang mempunyai keanekaragaman mangrove yang tinggi. Tingginya keanekaragaman mangrove ini menyediakan banyak jenis propagul mangrove yang dapat dimanfaatkan sebagai sumber benih. Karena di dalam kegiatan rehabilitasi mangrove membutuhkan propagul dan bibit yang sehat maka dengan banyaknya jenis mangrove yang menghasilkan propagul menjadi sumber bibit yang mendukung terhadap kegiatan rehabilitasi mangrove. Keuntungan yang diperoleh dari adanya pembibitan ini adalah bibit tanaman yang sehat, mempunyai tingkat pertumbuhan yang tinggi saat ditanam, dan memberikan pemasukan bagi masyarakat yang bekerja di pembibitan.

Pembibitan yang didirikan di dekat lokasi rehabilitasi menyediakan lapangan kerja dan keterlibatan masyarakat lokal. Selain itu, bibit memiliki kelangsungan hidup 100\% dan tersedia untuk transplantasi dalam waktu tiga bulan, dengan biaya yang murah (Nguyen, Tong, Quoi, \& Parnell, 2016). Daupan (2016), menambahkan bahwa kebijakan pengelolaan hutan mangrove berbasis masyarakat dapat meningkatkan partisipasi masyarakat lokal dalam pengelolaan hutan mangrove melalui pelibatan dalam kegiatan pembibitan, rehabilitasi, dan memanfaatkan hasil hutan non kayu.

Pemerintah Kota Langsa melalui dinas terkait sejak tahun 2015 telah melakukan kerjasama dengan akademisi dan Lembaga Swadaya Masyarakat Balee Jurong dalam kegiatan rehabilitasi mangrove di Kota Langsa. Bentuk kerjasamanya adalah melakukan penelitian dan rehabilitasi mangrove bersama masyarakat, alih pengetahuan tentang ekosistem mangrove, pelatihan pembuatan kebun bibit mangrove masyarakat dan pemberdayaan masyarakat di sekitar kawasan hutan mangrove. Masyarakat lokal yang memiliki pengetahuan tentang ekosistem mangrove akan memiliki sikap positif terhadap kegiatan rehabilitasi dibandingkan dengan masyarakat yang berpengetahuan rendah atau tidak sama sekali (Rönnbäck, Crona, \& Ingwall, 2007). Stone, Bhat, Bhatta, \& Mathews (2008), menambahkan bahwa keterlibatan masyarakat menjadi faktor kunci dalam meningkatkan potensi keberhasilan rehabilitasi ekosistem mangrove.

Pada tahun 2017, mulai dirintis usaha kebun bibit mangrove di areal Hutan Wisata Mangrove yang merupakan kerjasama antara PT. Pekola selaku pengelola Hutan Wisata Mangrove dengan pihak Lembaga Swadaya Masyarakat (LSM) Balee Jurong. Pada tapak kebun bibit ini banyak disemai jenis-jenis mangrove yang merupakan endemik di wilayah pesisir Kota Langsa. Dengan harmonisnya kerjasama ini, maka kendala tidak adanya bibit pada saat program rehabilitasi 
mangrove tidak terjadi. Untuk jangka panjang, diharapkan Kota Langsa menjadi salah satu lokasi penyedia bibit mangrove untuk wilayah Sumatera.

\section{SIMPULAN}

Seluruh parameter yang diukur sesuai dengan syarat tumbuh masing-masing jenis mangrove, sehingga kesesuaian lahan pada areal rehabilitasi hutan mangrove di Kota Langsa pada semua titik sampel pengamatan kriterianya adalah sesuai. Jenis Rhizophora spp. ditemui pada seluruh titik sampel pengamatan. Secara alami mengindikasikan bahwa jenis ini akan mendominasi jenis mangrove di Kota Langsa pada masa yang akan datang. Banyaknya jenis mangrove di Kota Langsa sangat mendukung terhadap keberhasilan rehabilitasi. Propagul yang melimpah dapat digunakan untuk pembibitan mangrove. Kebutuhan bibit untuk rehabilitasi dapat dipenuhi oleh kebun pembibitan yang dikelola oleh masyarakat di bawah binaan pemerintah Kota Langsa bekerjasama dengan akademisi dan lembaga swadaya masyarakat.

\section{REFERENSI}

Aksornkoae, S \& Kato, S. (2011). Mangroves for the people and environmental conservation in Asia. Bulletin of the Society of Sea Water Science, Japan. 65:3-9.

Alongi, D.M. (2008). Mangrove forests: resilience, protection from tsunamis, and responses to global climate change. Journal Estuarine Coastal and Shelf Science, (76): 1-13.

[Bapedda] Badan Perencanaan Pembangunan Daerah Kota Langsa. (2014). Peta sebaran kawasan hutan Kota Langsa. Langsa. Bapedda Kota Langsa.

Brown, B. \& Lewis, R.R. (2006). Five steps to successful ecological restoration of mangroves. Lewis, R. et al. (Eds.) Yogyakarta: Yayasan Akar Rumput Laut (YARL) and the Mangrove Action Project.

Carter, H.N., Schmidt, S.W., \& Hirons, A.C. (2015). An international assessment of mangrove management: incorporation in integrated coastal zone management. Journal Diversity, (7):74-104.

Daupan, S.M.M.V. (2016). Community Participation in Mangrove Forest Management in the Philippines: Management Strategies, Influences to Participation, and Socio-Economic and Environmental Impacts. (Thesis). Master of Science Natural Resources and Environment. University of Michigan. USA.

[DKPP Kota Langsa] Dinas Kelautan, Perikanan dan Pertanian Kota Langsa. (2014). Sebaran realisasi kegiatan bidang kehutanan. Langsa (ID): DKPP Kota Langsa.

Field, C. D. (1998). Rehabilitation of mangrove ecosystems: an overview. Marine Pollution Bulletin 37:383-392.

Giri, C., Long, J., Abbas, S., Murali, R.M., Qamer, F.M., Pengra, B., \& Thau, D. (2015). Distribution and dynamics of mangrove forests of South Asia. Journal of Environmental Management, 148:101-111.

Jusoff, K. (2013). Review: Malaysian mangrove forests and their significance to the coastal marine environment. Polish Journal Environmental Studies, 22: 979-1005.

Kathiresan, K. (2003). How do mangrove forests induce sedimentation? Tamil Nadu (IN). Revista de biologia tropical, 51(2): 355-360.

Kathiresan, K. (2012). Importance of mangrove ecosystem. International Journal of Marine Science, 2(10):70-89. 
Kodikara, K.A.S., Mukherjee, N., Jayatissa, LP., Dahdouh-Guebas, F., \& Koedam, N. (2017). Have mangrove restoration projects worked? An in-depth study in Sri Lanka. Restoration Ecology, 25(5):705-716.

Kusmana, C. (2014). Distribution and current status of mangrove forests in Indonesia. In: Mangrove ecosystem of Asia: status, challenges and management strategies. Farida-Hanum I., Latiff A., Hakeem K. R., Ozturk M. (eds), Springer, pp. 37-60.

Kusmana, C., Wilarso, S., Iwan, H., Pamoengkas, P., Wibowo, C., Tiryana, T., Triswanto, A., \& Hamzah, Y. (2005). Teknik rehabilitasi mangrove. Bogor: Fahutan IPB.

Lavieren, H.V, Spalding, M., Alongi, D.A., Kainuma, M., Godt, M.C., \& Adeel, Z. (2015). Securing the future of mangroves. United Nations University Institute for Water, Environment and Health. Hamilton, Canada.

Melana, D.M., Atchue, J., Yao, C.E., Edwards, R., Melana, E.E., \& Gonzales, H.I. (2000). Mangrove management handbook. Coastal Resource Management Project of The Departement of Environment and Natural Resources. Manila, Philipinnes.

Mirrera, O.D., Ochiewo, J., Munyi, F., \& Muriuki, T. (2013). Heredity or traditional knowledge: Fishing tactics and dynamics of artisanal mangrove crab (Scylla) fishery. Ocean and Coastal Management, 84:119-129.

Nguyen, T.P., Tong V.A., Quoi, L.P., \& Parnell, K.E. (2016). Mangrove restoration: establishment of a mangrove nursery on acid sulphate soils. Journal of Tropical Forest Science, 28: 275-84.

Noor, Y.R., Khazali, M., \& Suryadiputra, I.N.N. (2006). Panduan pengenalan mangrove di Indonesia. Bogor (ID): Ditjen PHKA, Wetlands International-Indonesian Programme.

Odum, W. E., Mclvor, C.C., \& Smith, III. I.J. (1982). The ecology of the mangroves of South.

Florida: a community profile. FWS/OBS-81/24. U.S. Department of the Interior, U.S. Fish and Wildlife Service, Office of Biological Services, Washington, D.C., USA.

Primavera, J.H., \& Esteban, J.M.A. (2008). A review of mangrove rehabilitation in the Philippines: successes, failures and future prospects. Wetlands Ecology and Management, 16:345-3 58.

Richards, D.R., \& Friess, D.A. (2016). Rates and drivers of mangrove deforestation in Southeast Asia, 2000-2012. Proceedings of the National Academy of Sciences of the United States of America, 12;113(2):344-349.

Rönnbäck, P., Crona, B., \& Ingwall, L. (2007). The return of ecosystem goods and services in replanted mangrove forests: perspectives from local communities in Kenya. Environmental Conservation, 34:313-324.

Saenger, P., Heger, E.J., \& Davies, J.D.S. (1983). Global status of mangrove ecosytem. Bangkok (Thai): IUCN.

[Satker] Satuan Kerja Badan Rehabilitasi dan Rekonstruksi NAD-Nias. (2008). Rehabilitasi hutan mangrove dan hutan pantai di pesisir Nanggroe Aceh Darussalam. Banda Aceh (ID): Pusat Pengendalian Lingkungan dan Konservasi BRR NAD-Nias.

Schmitt, K., \& Duke, N.C. (2016). Mangrove management, assessment, and monitoring. In: Pancel L., Köhl M. (eds) Tropical forestry handbook. Springer, Berlin, Heidelberg.

Spalding, M.D., Kainuma, M., \& Collins, L. (2010). World atlas of mangroves; Earthscan Ltd.: Washington, DC, USA. 
Stone, K., Bhat, M., Bhatta, R., \& Mathews, A. (2008). Factors influencing community participation in mangroves restoration: a contingent valuation analysis. Ocean \& Coastal Management, $51: 476-484$.

Thomas, N., Lucas, R., Bunting, P., Hardy, A., Rosenqvist, A., \& Simard, M. (2017). Distribution and drivers of global mangrove forest change, 1996-2010. PLoS One. 12:e0179302.

Wenqing, W., Zhongzheng, Y., Siyang, Y., Yihui, Z., Luzhen, C., \& Guanghui, L. (2011). Mangroves: obligate or facultative halophytes? A review. Research Gate. Trees 25:953-963. 